\title{
Clinical and statistical evaluation of new-patients at temporomandibular disorders clinic of Kyushu Dental College Hospital
}

Tomomi Ohmaru, Takahiko Matsuki, Jin Ohmaru, Hiroko Tsuda, Eri Makihara, Masahiro Arita and Shin-ichi Masumi (First Department of Prosthetic Dentistry, Kyushu Dental College)

159 patients who visited the Temporomandibular Disorders Clinic of Kyushu Dental College Hospital from April 1st, 2003 to March 31st, 2004, were evaluated their gender, age, chief complaint, type of disorders, treatment method, and treatment term. The number of patients decreased comparing with last year. Ratio of male to female was 1:3.4. Their chief complaints were matched to pathophysiology of each TMD type. It was thought that we have to apply physiotherapy much more in combination with other treatment methods.

\section{P - 14. 九州歯科大学附属病院保存治療科で用いている歯内治療用パスの有用性の検証}

○矢野 淳也·北村 知昭·諸富 孝彦·寺下 正道

九歯大·保存 1

近年, 歯科医療の質を高めるためにクリティカル・パスの重要性が認識されつつある. 歯内治療用パスによる治療 結果より作成したパスの妥当性について検討した。保存治療科の歯内治療用パスで歯内治療をした 213 名を対象と し，治療回数および治療法を分析した．治療回数は，Pulでは $85 \%$ 程度，Per でも $78 \%$ 程度が 4 回目までに根管充

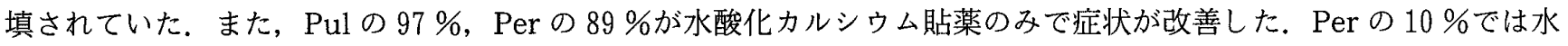
酸化カルシウム以外に抗生剂を貼薬したり外科的処置を併用していた．今回，歯内治療を要する全症例の約 8 割は治 療回数 4 回以内で改善し, 水酸化カルシウムを用いた治療で 9 割が改善していることから, 私達の作成した歯内治療 用パスが適切であることが示された.

The research of availability of the critical pathway for the endodontic treatment of the department of operative dentistry in Kyusyu Dental College Hospital

Junya Yano, Chiaki Kitamura, Takahiko Morotomi and Masamichi Terashita (Department of Operative Dentistry, Kyushu Dental College Hospital)

The importance of the critical pathway is broadly recognized for the advancement of dental treatment. Since we made the critical pathway for the endodontic treatment in operative dentistry in Kyusyu Dental College Hospital two years ago, we treated the 213 patients on this pathway. On this study, we collected the therapeutic results of this treatment method, and we discussed the validity of this pathway. More than $80 \%$ of all endodontic treatment was finished within the four treatment times. About $90 \%$ of all cases were recovered by only use of calcium hydroxide. The residual cases were healed by antibiotic or surgical methods that followed this pathway. These results showed the validity of this pathway.

\section{$P-15$. 総義歯が咀嚼・嚥下機能に与える影響に関する研究}

$\begin{array}{rrrrr}\text { O椎葉 } & \text { 俊司·松本 } & \text { 吉洋·吉成 } & \text { 正典·坂本 } & \text { 英治·吉田 } \\ \text { 原野 } & \text { 望·甲広 } \\ \text { 斐 } & \text { 絢·河原 } & \text { 博·仲西 修 }\end{array}$

九歯大 $\cdot$ 歯麻酔

脳血管障害後患者の問題の一つに誤與性肺炎がある，今回，健常成人ではあるが義歯使用の摂食・燕下機能に与え る影響をVideo Fluorographyによって検討した，対象は義歯新製执よび調整を希望する健常成人合計 10 名とし た。食物はバリウム溶液，バリウムに浸したゼリーとバリウム溶液十ゼリーの3 種類とした。解析は誤燕と関連性を 有する與下開始時点の食物先端の位置, 咀嚼・嬹下の各位相の食物通過に要する時間および咀嚼終了時より與下開始 までの時間の 3 項目とした。曣下時食物先端位置は混合物で咽頭・喉頭部に達する傾向や通過時間が長い傾向が認め られ，これらは義歯使用によって軽減されることが解った。 また，混合物では咀嚼終了前に燕下が開始される傾向が 
認められた．食物形態の工夫や義歯使用が器與性肺炎を抑制する可能性がある.

\section{The inflvence that complete dentvre gives on ingestion and deglutition function}

Shunji Shiiba, Yoshihiro Matsumoto, Masafumi Yoshinari, Eiji Sakamoto, Mitsuhiro Yoshida, Nozomu Harano, Aya Kai, Hiroshi Kawahara and Osamu Nakanishi (Department of Dental Anesthesiology, Kyushu Dental College)

The patient after cerebral vascular disturbance is easy to have aspiration pneumonitis. We reviewed the influence that a denture gave for chewing / a deglutition function with Video Fluorography. The subjects were ten healthy adults hoping for a new production of denture and adjustment. Aspiration and food apical lie of deglutition base line having relevance, diet of members phase of chewing / deglutition were transit and did the analysis with temporal three items to deglutition initiation from time to need and chewing end time. The place of food tip place has reached a pharynx / laryngeal in a mixture in deglutition. These are reduced by artificial denture use. The tendency that deglutition was started before the masticatory end in compound foods, was observed. There is a possibility that an idea food configuration and a denture use inhibit aspiration pneumonitis.

\section{$P$ - 16. 九州歯科大学附属病院を受診した口腔乾燥症患者におけるドライマウス検査結果と病態の関連について}

○安細 敏弘 ${ }^{1} \cdot$ 新屋敷真実 ${ }^{1} \cdot$ 吉田 明弘 ${ }^{1} \cdot$ 冨永 和宏 ${ }^{2} \cdot$ 高橋 哲 $^{3} \cdot$ 西原 達次 $^{4} \cdot$ 竹原 直道 ${ }^{1}$ 九歯大·予歯, ${ }^{2}$ 九歯大·口外 $1,{ }^{3}$ 九歯大·口外 $2,{ }^{4}$ 九歯大·微生物

近年, 口腔乾燥を主訴として来院する患者が増加しており, ドライマウス患者に対する診療システムの構築が急務 である. 本研究では, ドライマウス検查を受診した患者 118 名のデー夕を基に検查結果と病態との関連を統計学的に 解析した。判別分析の結果, 口腔乾燥の臨床所見と有意に関連がみられた因子は, 粘膜湿潤度と安静時唾液流出量で あった。一方, 口腔乾燥の自覚症状と有意な関連がみられた因子は, 服薬の有無, 「乾いた食品が食べにくい」, 「舌 がピリピリする」,「目が乾きやすい」であった。これらの結果から, 口腔乾燥症の評価方法としては, 自覚症状の問 診, 服薬調查に加えて, 粘膜湿潤度検査と安静時唾液流出量検査が有用であることが示唆された.

Association between clinical tests for dry mouth and symptoms of dry mouth on outpatients at the dry mouth clinic in Kyushu Dental College Hospital

Toshihiro Ansai ${ }^{1}$, Mami Shinyashiki ${ }^{1}$, Akihiro Yoshida ${ }^{1}$, Kazuhiro Tominaga ${ }^{2}$, Tetsu Takahashi ${ }^{3}$, Tatsuji Nishihara ${ }^{4}$ and Tadamichi Takehara ${ }^{1}\left({ }^{1}\right.$ Department of Preventive Dentistry, ${ }^{2}$ First Department of Oral and Maxillofacial Surgery, ${ }^{3}$ Second Department of Oral and Maxillofacial Surgery and ${ }^{4}$ Department of Oral Microbiology, Kyushu Dental College)

Most recently, the number of patients who complain of dry mouth is increasing. Therefore, there is an urgent need for the establishment of an effective diagnostic system of dry mouth. The aim of this study is to statistically analyze the association between clinical tests for dry mouth and symptoms of dry mouth in 118 outpatients at the Kyushu Dental College Hospital. Discriminant analysis suggested that the useful diagnostic assessment for dry mouth would be the tongue dorsum moisture and resting salivary flow rate tests as well as medical questionnaire consisting of questions relating to symptoms of dry mouth and investigation of medications.

\section{$P$ - 17. 高齢者の残存歯数と酸化ストレスおよび脈波伝播速度による動脈硬化性疾患の評価との関係 ○園木 一男 ${ }^{1} \cdot$ 高田 豊 ${ }^{1} \cdot$ 安細 敏弘 ${ }^{2} \cdot$ 福原 正代 $^{1} \cdot$ 秋房 $^{\text {住郎 }}{ }^{2}$ 藤澤 聖 ${ }^{1} \cdot$ 濱崎 朋子 ${ }^{2} \cdot$ 脇坂 正則 ${ }^{1} \cdot$ 竹原 直道 ${ }^{2}$ \\ ${ }^{1}$ 九歯大 ·内科, ${ }^{2}$ 九歯大 ·予歯}

平成 15 年の福岡県 85 歳高齢者住民の追跡調查の対象者 207 名で, 残存㐘数が酸化ストレスや動脈硬化に関係があ るのか検討した. 残存歯数と過酸化脂質には相関があり, 残存歯数が多いほど過酸化脂質は低下した. 残存歯数 20 本 